Article

\title{
Response of Mid-Rotation Loblolly Pine (Pinus taeda L.) Physiology and Productivity to Sustained, Moderate Drought on the Western Edge of the Range
}

\author{
Adam Maggard ${ }^{1, *}$, Rodney Will ${ }^{1}$, Duncan Wilson ${ }^{2}$ and Cassandra Meek ${ }^{1}$ \\ 1 Department of Natural Resource Ecology and Management, Oklahoma State University, Stillwater, \\ OK 74078, USA; rodney.will@okstate.edu (R.W.); cassandrameek@gmail.com (C.M.) \\ 2 South Central Climate Science Center, University of Oklahoma, Norman, OK 73019, USA; \\ dunc.wilson9@gmail.com \\ * Correspondence: adam.maggard@okstate.edu; Tel.: +1-352-999-0654 \\ Academic Editor: Timothy A. Martin \\ Received: 29 July 2016; Accepted: 7 September 2016; Published: 14 September 2016
}

\begin{abstract}
The productivity of the approximately 11 million ha of loblolly pine plantations in the southeastern USA could be threatened by decreased water availability in a future climate. To determine the effects of sustained drought on leaf gas exchange, whole-tree water use, and individual tree growth, we examined the response of loblolly pine trees to $100 \%$ throughfall exclusion cumulatively spanning the sixth and seventh growing seasons of a plantation in southeastern Oklahoma. Throughfall exclusion reduced volumetric soil water content for $0-12 \mathrm{~cm}$ soil depth from $10.8 \%$ to $4.8 \%$ and for $12-45 \mathrm{~cm}$ soil depth from $24.2 \%$ to $15.6 \%$. Compared to ambient throughfall trees, leaf water potential of the throughfall exclusion trees became more negative, $-0.9 \mathrm{MPa}$ vs. $-1.3 \mathrm{MPa}$ for predawn measurements and $-1.5 \mathrm{MPa}$ vs. $-1.9 \mathrm{MPa}$ for midday measurements. Throughfall exclusion did not significantly reduce leaf gas exchange or tree water use. However, throughfall exclusion significantly reduced leaf biomass by $21 \%$ and stem volume growth by $23 \%$. These results indicate that sustained drought may cause downward shifts in leaf quantity to conserve water rather than reducing leaf-level water use.
\end{abstract}

Keywords: leaf biomass; leaf gas exchange; Pinus taeda; sustained drought; throughfall exclusion; water use

\section{Introduction}

Planted pines account for $19 \%$ of all forests in the southeastern USA [1] with loblolly pine (Pinus taeda L.) plantations accounting for over $50 \%$ of these pine plantations [2]. Therefore, loblolly pine plantations are important sources of productivity that could be threatened by decreased water availability in years to come $[3,4]$. Atmospheric $\mathrm{CO}_{2}$ is increasing and changes in temperature and precipitation regimes are expected to impact the southeastern USA [3]. Increases in intensity and more irregular occurrences of precipitation events across the region are predicted, with no change to total annual precipitation. However, greater rainfall intensity and increased number of dry days between events may increase runoff, reducing soil water availability [4]. Increases in mean annual temperature by the end of this century are predicted to be between 2.5 and $4.0^{\circ} \mathrm{C}$ for this region [4]. Increases in temperature cause greater vapor pressure deficit (VPD) and evapotranspiration, thus increasing the potential for tree water stress $[5,6]$. Therefore, the combined effects of increased temperature and decreased soil water availability are predicted to increase the frequency and severity of drought $[3,4]$. 
This is especially important for the western edge of the loblolly pine range, which already experiences higher growing season temperatures and VPD than the more eastern part of the range [7].

Reduced water availability decreases tree growth and can ultimately lead to mortality, depending on the longevity and severity of drought events [8-10]. During recent years, drought has been linked to widespread tree mortality events [11-13]. During drought, reduced stomatal conductance or stomatal closure is one of the earliest tree responses [14], which reduces net photosynthesis and subsequently growth $[9,15]$. During longer or more intense droughts, structural modifications can occur, such as reductions in leaf area or leaf biomass $[8,15,16]$. In a loblolly pine stand in southeastern Oklahoma, it was found that leaf biomass production was reduced in drier years compared to years when water availability was more abundant [17].

Leaf area or leaf biomass is commonly studied because it is an important determinant in tree-level water use and carbon gain. Trees with a greater quantity of leaves typically have greater total transpiration than trees with a smaller quantity. Failure to reduce transpiration rates during drought can harm trees by leading to dehydration and injury, or possibly death [8]. Changes in stomatal conductance are associated with changes in leaf specific hydraulic conductance [18], indicating that with increasing leaf area or biomass, reductions in stomatal conductance are essential in order to avoid leaf water potentials that might cause cavitation [19]. During drought, early abscission of leaves can occur which reduces shoot water loss and helps conserve resources [20]. Water stress can lead to early abscission in loblolly pine and shift peak needle fall up to two months earlier [17].

Effects of long-term drought [21-23] and induced drought [24-27] on tree mortality and survival have been documented for numerous species $[13,28-30]$. However, research on the effects of drought on loblolly pine has focused on seedlings [15,31-33], short-term natural drought [34-36], or induced moderate drought [37-41]. During short-term, natural drought or induced, moderate drought (removal of $30 \%$ of throughfall), loblolly pine typically exhibit more negative water potentials and respond by reducing stomatal conductance to avoid water loss [15,38,42]. We currently lack an understanding of how sustained, more severe droughts will impact the physiology and productivity of loblolly pine.

The objective of this study was to determine the effects of sustained drought on leaf gas exchange, whole-tree water use, and individual tree growth. To accomplish this objective, we examined the response of individual, mid-rotation (ages 6-7) trees to 100\% throughfall exclusion. Our central hypothesis was that sustained elimination of throughfall would cause more negative leaf water potentials and decrease leaf gas exchange, tree water use, leaf biomass, and tree growth. Further, we hypothesized that leaf gas exchange would be the most pronounced change such that water use per sapwood area would be much lower with throughfall elimination. Determining the effects of sustained drought is important for understanding physiological and structural responses as well as mechanisms that contribute to acclimation and survival.

\section{Materials and Methods}

\subsection{Study Site}

The study took place from March 2013, through September 2014, which spanned the sixth and seventh growing seasons of a loblolly pine stand near Broken Bow, Oklahoma $\left(34^{\circ} 01^{\prime} 47^{\prime \prime} \mathrm{N}\right.$, $\left.94^{\circ} 49^{\prime} 23^{\prime \prime} \mathrm{W}\right)(\sim 157 \mathrm{~m}$ above sea level). Soils had 3 to 8 percent slopes and consisted of Ruston series (Fine-loamy, siliceous, semiactive, thermic Typic Paleudult). These soils are characterized as very deep, fine sandy loam typical for forests on the uplands of the western and southern Coastal Plain [43]. Mean annual precipitation for Broken Bow, OK, since stand establishment (January 2008) was $1313 \mathrm{~mm}$, with the greatest average monthly precipitation occurring in May $(151 \mathrm{~mm})$ and the least occurring in August $(79 \mathrm{~mm})$. Annual mean, average maximum, and average minimum temperatures for Broken Bow, OK since stand establishment were $16.0^{\circ} \mathrm{C}, 23.2^{\circ} \mathrm{C}$, and $9.3^{\circ} \mathrm{C}$ [44].

Site preparation prior to planting included $680 \mathrm{~g} \cdot \mathrm{ha}^{-1}$ of Chopper $^{\circledR}(27.6 \%$ imazapyr, $72.4 \%$ inert ingredients) (BASF Corporation, Florham Park, NJ, USA) plus $2.8 \mathrm{~L} \cdot \mathrm{ha}^{-1}$ of glyphosate $(53.8 \%$ 
active ingredient, $46.2 \%$ other) applied in August 2007 followed by a prescribed burn in October 2007. In November 2007, the site was subsoiled along the contour to depths of 51 to $61 \mathrm{~cm}$ using a D8 Caterpillar dozer and subsoiling shanks (Caterpillar Corporate, Peoria, IL, USA). In January 2008, the site was planted at an approximate spacing of $2 \mathrm{~m} \times 3 \mathrm{~m}\left(\sim 1650\right.$ trees $\left.^{-h^{-1}}\right)$ with improved Western Gulf Tree Improvement Cooperative 1-0 bare-root seedlings originating from a mix of half-sib families. In March 2008, a mix of $420 \mathrm{~g} \cdot \mathrm{ha}^{-1}$ of Arsenal $^{\circledR}$ (27.6\% imazapyr, $72.4 \%$ inert ingredients) (BASF Corporation, Florham Park, NJ, USA) and $175 \mathrm{~g} \cdot \mathrm{ha}^{-1}$ of Oust Extra ${ }^{\circledR}(56.25 \%$ Sulfometuron methyl, 15.0\% Metsulfuron methyl, 28.75\% other) (E.I. Du Pont De Nemours and Company, Wilmington, DE, USA) was applied for woody plant and herbaceous weed control.

\subsection{Experimental Design}

The study was a randomized complete block design consisting of five blocks. Each block consisted of two trees (10 trees total), one each of $100 \%$ throughfall exclusion (TE) and ambient throughfall treatments (TA) (Figure 1). Within the stand, this experiment was located where trees had relatively uniform height and diameter at breast height (DBH) and soils were presumed consistent. The location was along a broad ridge (approximately $50 \mathrm{~m}$ wide) in an effort to minimize subsurface water flow and increase chances of above- and subsurface water flow away from treatment blocks. To prevent root expansion beyond treatment areas, all 10 trees were trenched. Trenches were excavated to approximately $60 \mathrm{~cm}$. A $2 \times 3 \mathrm{~m}$ rectangle representing the growing space of each stem was trenched around each treatment tree. Trenches between rows were excavated with a ride-on trencher (Ditch Witch RT40, Perry, OK, USA) and trenches between across rows were excavated with Zahn walk-behind trencher (Ditch Witch R150, Perry, OK, USA). Trenches were lined with 6 mil heavy duty plastic polyethylene (BLUE HAWK LF, LLC, Mount Mourne, NC, USA) and back-filled with soil. Competing vegetation was chemically eliminated using directed sprays of glyphosate ( $2 \%$ a.i., Roundup ${ }^{\circledR}$, Monsanto Company, St. Louis, MO, USA) from March 2013 through the remainder of the study.

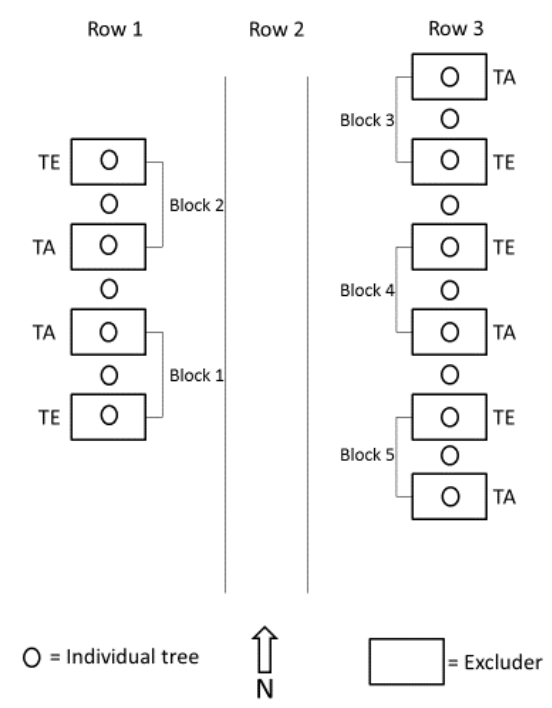

Figure 1. Diagram of study site showing treatment design and block layout for $100 \%$ throughfall exclusion (TE) and ambient throughfall (TA) treatments.

The TE treatment consisted of $3.7 \mathrm{~m}$ by $2.7 \mathrm{~m}$ excluders built around each tree (Figure 2). Excluders were installed in February 2013 and were built of lumber and covered with clear 6 mil heavy duty plastic polyethylene (BLUE HAWK LF, LLC, Mount Mourne, NC, USA). Covers were monitored and replaced as needed. Excluders were approximately $1.1 \mathrm{~m}$ in height at the tree sloping to approximately $0.8 \mathrm{~m}$ to allow precipitation runoff and air flow to circulate underneath. Excluders extended approximately 
$0.3 \mathrm{~m}$ beyond the trenches. Branches below excluders were removed to prevent shading of the soil surface and potential damage to excluder covers. Stemflow was diverted onto excluders by securing cone shaped polyethylene around the tree above excluders. Excluders were designed the same way for TA trees to minimize possible microclimate differences beneath excluders between treatments. Openings were cut into the polyethylene to allow throughfall to reach the soil for TA treatments.

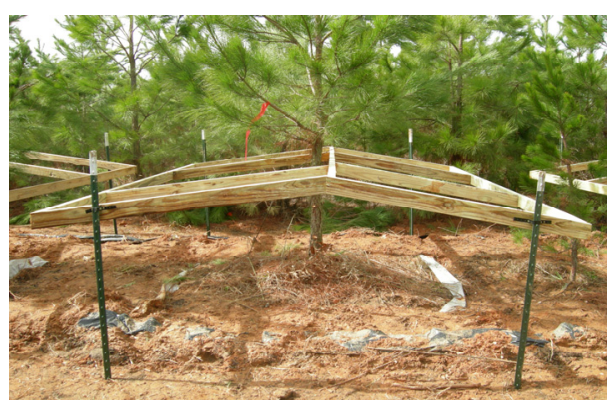

(a)

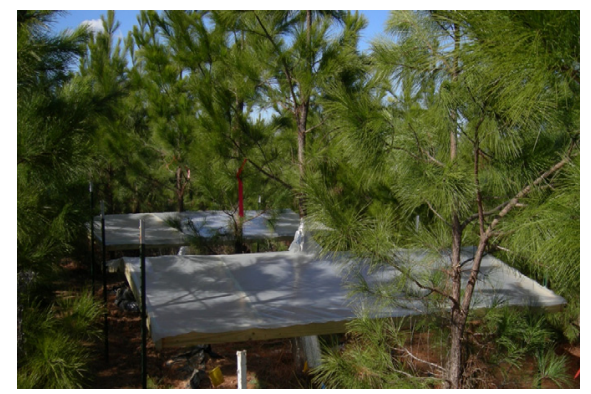

(b)

Figure 2. (a) Photograph of individual excluder during construction and (b) photograph of excluders following completion of construction at the study site in southeastern Oklahoma.

\subsection{Environmental Variables}

Climate variables were measured on site using meteorological sensors mounted at the top of a tower located in an opening within the stand. Sensors included a CS215 air temperature and relative humidity probe (Campbell Scientific, Logan, UT, USA) and a TR-525M remote tipping bucket precipitation sensor (Texas Electronics, Inc., Dallas, TX, USA). Data were recorded every 15 min using a CR1000 data logger (Campbell Scientific, Logan, UT, USA). Data gaps from sensor malfunctions or power outages were backfilled using data from the Broken Bow, OK $\left(34^{\circ} 02^{\prime} 35^{\prime \prime} \mathrm{N}\right.$, $94^{\circ} 37^{\prime} 27^{\prime \prime}$ W) Oklahoma Mesonet environmental monitoring station via data request from the Oklahoma Climatological Survey. Vapor pressure deficit (VPD, kPa) was calculated from relative humidity and temperature measurements based on published protocols [45]. Mean monthly daytime VPD was determined by averaging daily 15-min VPD calculations between sunrise and sunset times for Broken Bow, OK (Astronomical Applications Department, U.S. Naval Observatory).

\subsection{Volumetric Soil Water Content}

Volumetric soil water content (VWC) was measured by time domain reflectometry (TDR) using a 1502C metallic TDR cable tester (Tektronix, Inc., Beaverton, OR, USA) taken every seven to ten days during the sixth growing season and every four to six weeks during winter months and throughout the seventh growing season. Beneath each excluder, one pair of vertical, stainless steel rods for $0-12 \mathrm{~cm}$, 0-45 cm, and 0-90 cm soil depths were installed on the south side of the tree approximately $0.3 \mathrm{~m}$ apart and $0.6 \mathrm{~m}$ from the base of the tree. All measurement depths per tree were measured each sampling round.

\subsection{Physiology}

Measurements of leaf gas exchange were conducted from March 2013 through September 2014. Measurements were conducted bi-weekly during the 2013 growing season and every four to six weeks during the winter months. For 2014, measurements were conducted approximately every four weeks during the growing season and every six to eight weeks during the winter months. All measurements were taken using an LI-6400 portable photosynthesis system (LiCor Inc., Lincoln, NE, USA). Measured variables included net photosynthesis $\left(\mathrm{P}_{\text {net }}\right)$, stomatal conductance $\left(\mathrm{g}_{\mathrm{s}}\right)$, and intercellular $\mathrm{CO}_{2}$ concentration $\left(\mathrm{C}_{\mathrm{i}}\right)$. Leaf gas exchange was measured on all trees (10 total). For each tree on each measurement date, two fascicles were sampled that developed in full sun in the upper third of the 
tree on the south side. Needles were collected by hand in 2013 and by a pole pruner in 2014. Fascicles from the first flush of 2012 were measured from March to July 2013 while the first flush of 2013 was measured from August 2013 to July 2014 and the first flush of 2014 was measured from August 2014 through September 2014. Within sampling dates, measurements were taken between 1300 and $1500 \mathrm{~h}$.

During leaf gas exchange measurements, photosynthetic photon flux density $\left(1800 \mu \mathrm{mol} \cdot \mathrm{m}^{-2} \cdot \mathrm{s}^{-1}\right)$ and reference $\mathrm{CO}_{2}$ concentration $\left(400 \mu \mathrm{mol} \cdot \mathrm{mol}^{-1}\right)$ were held constant inside the leaf chamber. For the majority of measurements, relative humidity $(\mathrm{Rh})$ within the chamber $(2 \times 3 \mathrm{~cm})$ was not controlled and fluctuated with ambient conditions. All-sided leaf area in the cuvette was calculated based on measuring the radius of one needle per fascicle using a scale loupe. Specific leaf area of foliage used for gas exchange measurements was calculated by drying and weighing the foliage from the cuvette and calculating the ratio between area/weight. Samples for midday leaf water potential $\left(\Psi_{\mathrm{L}}\right)$ measurements were collected in unison with leaf gas exchange measurements. Samples for predawn leaf water potential $\left(\Psi_{\mathrm{L}}\right)$ were collected from the same canopy location as those for midday $\Psi_{\mathrm{L}}$. Measurements of predawn $\Psi_{\mathrm{L}}$ were conducted the mornings before leaf gas exchange measurements between $400 \mathrm{~h}$ and $600 \mathrm{~h}$, finishing at least $30 \mathrm{~min}$ before sunrise. Midday $\Psi_{\mathrm{L}}$ and predawn $\Psi_{\mathrm{L}}$ were measured using a PMS 600 pressure chamber (PMS, Instrument Corp., Corvallis, OR, USA).

Stable carbon isotope ratio $\left({ }^{13} \mathrm{C} /{ }^{12} \mathrm{C}\right)$ and nitrogen concentration were determined for the foliage used for leaf gas exchange measurements. For each tree, foliage was grouped by foliage cohort and dried at $60{ }^{\circ} \mathrm{C}$ for at least $48 \mathrm{~h}$ before measurement. Measurements were conducted at the Texas A\&M University Stable Isotopes for Biosphere Science Laboratory using an ECS 4010 CHNSO analyzer (Costech Analytical Technologies, Inc., Valencia, CA, USA) coupled with Thermo Conflo IV and Thermo Delta V Advantage stable isotope mass spectrometer (Thermo Fisher Scientific, Inc., Waltham, MA, USA). Relative to the reference material, Pee Dee Belemnite, the ${ }^{13} \mathrm{C} /{ }^{12} \mathrm{C}$ ratios of the samples were normalized and expressed in delta $(\% 0)$ units.

\subsection{Peak Foliage Mass}

Sampling was conducted on 20-21 August 2015 to capture peak leaf biomass for the 2015 growing season (i.e., both the 2014 and 2015 foliage cohorts). At that point, a small portion of the lower foliage in the 2014 cohort had senesced and that senescence was mostly associated with the death of lower branches from canopy shading. As this measurement was semi-destructive, we waited until we had completed the experiment. As a result, leaf biomass data are for the 2014 and 2015 cohorts while leaf gas exchange and tree water use data are for 2013 and 2014. Treatments were maintained for the entirety of 2015.

For each tree, the diameter at insertion $(2 \mathrm{~cm}$ from the main stem) for all live branches was measured up to a height of $5.5 \mathrm{~m}$. One branch per whorl was randomly selected and harvested with hand clippers and foliage was separated into the 2014 and 2015 cohorts, placed in paper bags, dried at $60{ }^{\circ} \mathrm{C}$ for at least $48 \mathrm{~h}$, and weighed. For whorls higher than $5.5 \mathrm{~m}$, one branch per whorl was harvested with a pole pruner and its diameter measured. The diameters of the remaining branches were estimated by eye (from less than $1.5 \mathrm{~m}$ away) based on the measured diameter of the harvested branch and the relative size difference of the attached branches. Foliage from the main stem was not measured. When a fork occurred (two of ten trees), the smaller of the forks was harvested and all foliage from the fork was collected.

The relationship between branch diameter squared $\left(\mathrm{BD}^{2}\right)$ and foliage biomass was determined for each tree and foliage cohort separately. Based on these relationships, the lowest 0 to 3 whorls (depending on the tree) were excluded from each regression analysis because the lowest whorls had disproportionately low leaf biomass per $\mathrm{BD}^{2}$ due to shading effects. These lowest branches had developed to support previous cohorts. After removing the lowest branches from the analysis, the results were linear relationships between foliage biomass and $\mathrm{BD}^{2}$. The average $r^{2}$ was 0.63 and 0.67 for 2014 and 2015 foliage cohorts, respectively. 
To estimate the leaf biomass of each tree and cohort, the leaf biomass of the non-harvested branches was estimated using the regression relationships, and the foliage biomass of all branches was summed. For lower branches in whorls that were not included in the regression analysis, the biomass of harvested branches was added to the total, and the biomass of non-harvested branches was estimated relative to the harvested branch for that whorl (i.e., (diameter squared of unharvested branch/diameter squared of harvested branch) $\times$ leaf biomass of harvested branch). For the two trees with forks, forks were not included in the regression analysis and the foliage biomass of the fork was included in the total.

\subsection{Growth}

Tree size was measured in February 2013 prior to treatment application (following the fifth growing season), in January 2014 (following sixth growing season), and in January 2015 (following seventh growing season). Measurements included DBH and height. DBH was measured using a diameter tape. Height was measured prior to treatment application and following the sixth growing season using a height pole. Height was measured following seventh growing season using a hypsometer (Laser Technology, Inc., Centennial, CO, USA). DBH, height, and volume growth [46] were determined from the difference in successive dormant season measurements.

\subsection{Water Use}

Sap flow density was measured using thermal dissipation probes (TDPs) that consisted of 19 gauge $38.1 \mathrm{~mm}$ stainless steel hypodermic needles that were cut to $20 \mathrm{~mm}$ in length [47] and constructed in the tree physiology laboratory at Oklahoma State University. Probes were inserted beneath excluders on the north side of each tree. Probe height ranged from $0.73 \mathrm{~m}$ to $0.42 \mathrm{~m}$ above the ground. All trees contained one probe set (total 10 probe sets). All probes were initially inserted in February 2013. Probes were wrapped with reflective insulation to minimize thermal gradients. Probes were monitored through weekly data downloads and screened for malfunctions and errors. Malfunctioning probes were replaced by new probes in the same tree at least $25 \mathrm{~mm}$ from the original location. New probes were not expected to provide the same readings as original probes due to variation in sapwood conductivity [48,49], and each replacement was treated as a separate probe. Therefore, the actual number of probes in the study varied in the analysis based on the number of replacements.

The temperature differential between the upper probe (heated at a constant 0.2 watts) and lower probe (unheated) was measured every two minutes beginning from initial probe insertion and recorded by a data logger (model CR1000, Campbell Sci., Logan, UT, USA). Data from March 2013 through September 2014 are presented. Sap flux was calculated according to [50] by solving the flow index $(K)$ using Equation (1):

$$
K=\left(\Delta T_{\max }-\Delta T\right) / \Delta T
$$

where $\Delta T_{\max }$ is the maximum temperature difference established between the heated and non-heated probes at zero flux and $\Delta T$ is the temperature difference between heated and non-heated probes at a given sap flux density and using $K$ to calculate sap flux velocity $(V)$ (see Equation (2)):

$$
V=0.000119 \times K^{1.231}\left(\mathrm{~m} \cdot \mathrm{s}^{-1}\right)
$$

$V$ was converted to sap flux (see Equation (3)):

$$
J_{s}=S A \times V\left(\mathrm{~m}^{3} \cdot \mathrm{sec}^{-1}\right)
$$

where $S A$ is sapwood area in $\mathrm{m}^{2}$. Finally, these instantaneous measurements were converted to units of sap flux in liters per day. Sapwood area for all trees in this study was assumed to be the cross sectional area at probe height minus bark thickness, due to the fact that the trees were eight years old at the end of the experiment, which is younger than the age when heartwood development begins in 
loblolly pine [51]. This was confirmed by coring five dominant sized trees in the plantation, outside the measurement plots.

\subsection{Statistical Analysis}

For all measurements, treatment effects were analyzed using repeated measures analysis (Proc Mixed, SAS Inc., Cary, NC, USA) with block as a random factor and treatments as fixed factors and the autoregressive 1 (AR1) covariance structure. When there was a significant interaction involving year, treatment effects within year were tested using the SLICE statement in Proc Mixed. Daily tree water use was summed per week for analysis. Growth data was square root transformed to homogenize variance among trees. Each tree was an experimental unit $(n=5)$ and treatment effects were considered significant at $p<0.1$.

\section{Results}

\subsection{Environmental Variables}

Mean monthly average temperature was greatest in August in $2013\left(26.1^{\circ} \mathrm{C}\right)$ and $2014\left(25.4^{\circ} \mathrm{C}\right)$ and lowest in December $\left(4.3^{\circ} \mathrm{C}\right)$ in 2013 and January $\left(4.5^{\circ} \mathrm{C}\right)$ in 2014 . Overall mean monthly temperature for the measurement period (March 2013-September 2014) was $16.7^{\circ} \mathrm{C}$ (Figure 3a). Mean monthly daytime VPD was greatest in August in $2013(1.41 \mathrm{kPa})$ and $2014(0.92 \mathrm{kPa})$ and lowest in December in $2013(0.25 \mathrm{kPa})$ and $2014(0.17 \mathrm{kPa})$. Overall mean monthly daytime VPD for the measurement period was $0.77 \mathrm{kPa}$ (Figure 3b). Annual precipitation was $1190 \mathrm{~mm}$ in 2013 and $1046 \mathrm{~mm}$ in 2014. In 2013, the greatest monthly precipitation occurred in July (216 mm) and least occurred in August (8.1 mm). In 2014, the greatest monthly precipitation occurred in July (182 mm) and least occurred in August $(11 \mathrm{~mm})$. Total precipitation over the measurement period was $(1982 \mathrm{~mm})$ (Figure 3c).

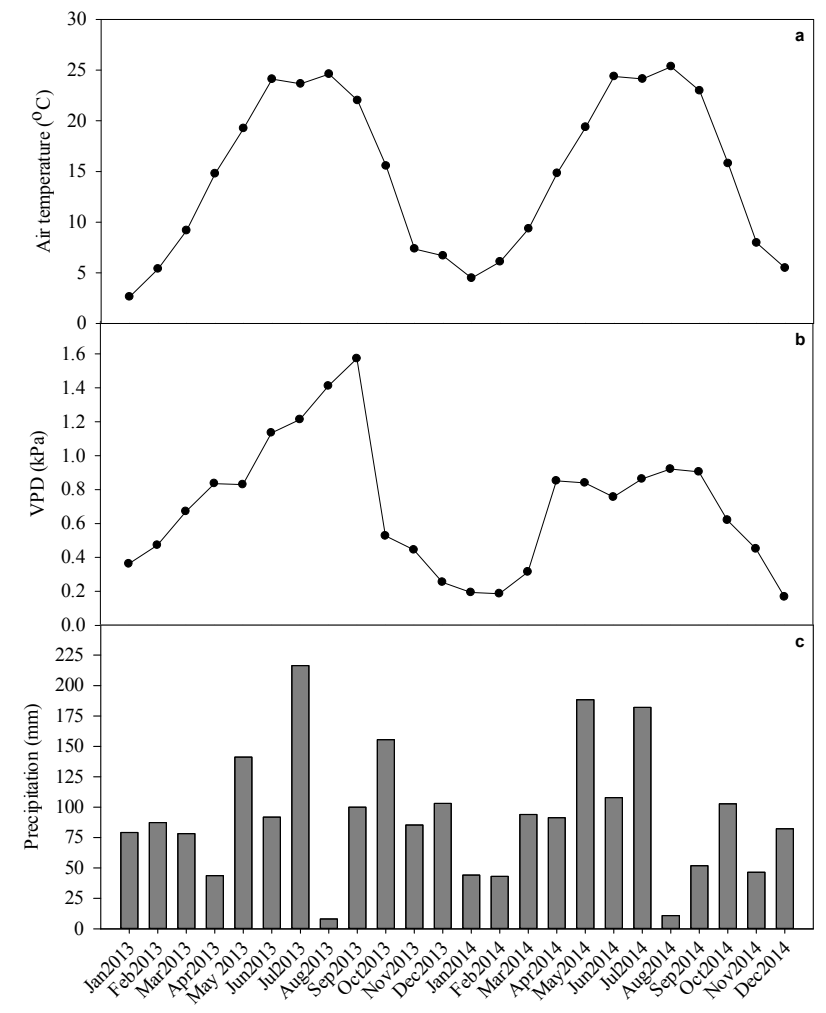

Figure 3. Mean monthly (a) air temperature; (b) mean monthly daytime vapor pressure deficit (VPD); and (c) total monthly precipitation for 2013 and 2014. 


\subsection{Volumetric Soil Water Content}

Throughfall exclusion reduced VWC from $0-12 \mathrm{~cm}$ soil depth except for dry periods when VWC also decreased in the TA treatment, causing treatment differences to compress (Table 1) (Figure 4). Across the measurement period, throughfall exclusion reduced VWC $0-12 \mathrm{~cm}$ soil depth by approximately one half, averaging $4.8 \% \pm 1.5 \%$ (averaging $\pm \mathrm{SE}$, same below) for the TE treatment and $10.8 \% \pm 2.9 \%$ for the TA treatment. Similar to VWC from $0-12 \mathrm{~cm}$ soil depth, throughfall exclusion reduced VWC from 12-45 cm soil depth except for dry periods when VWC also decreased in the TA treatment (Table 1, Figure 4). Across the measurement period, VWC of the TE treatment was reduced by approximately one third compared to the TA treatment, averaging $15.7 \% \pm 2.9 \%$ for the TE treatment and $24.2 \% \pm 3.1 \%$ for the TA treatment. Throughfall exclusion had little effect on VWC from $45-90 \mathrm{~cm}$ soil depth. A date $\mathrm{x}$ treatment interaction for VWC from $45-90 \mathrm{~cm}$ was caused by changes in the rank of treatment means (Table 1, Figure 4). Average VWC from 45-90 cm across the measurement was $27.4 \% \pm 2.8 \%$ and $26.0 \% \pm 2.8 \%$ for the TE and TA treatments, respectively. Over the last week of October 2013 and first week November 2013, the site received $213 \mathrm{~mm}$ of precipitation which is greater than 2.5 times the average monthly precipitation across the study period $(73 \mathrm{~mm})$. The intense precipitation over a short period of time caused a recharge in VWC at all depths across both treatments (Figure 4). However, the TE treatment maintained significantly lower VWC than the TA treatment.

Table 1. Statistical significance for the effects of date and throughfall exclusion (TE) on volumetric soil water content (VWC) from 0-12 cm, 12-45 cm, and 45-90 cm for the entire measurement period (2013-2014).

\begin{tabular}{cccc}
\hline & VWC 0-12 cm & VWC 12-45 $\mathbf{~ c m ~}$ & VWC 45-90 cm \\
\hline Date & $<0.0001$ & $<0.0001$ & $<0.0001$ \\
TE & $<0.0001$ & $<0.0001$ & 0.07 \\
Date $\times$ TE & $<0.0001$ & $<0.0001$ & 0.01 \\
\hline
\end{tabular}

\subsection{Peak Foliage Mass}

Averaged across the 2014 and 2015 foliage cohorts, throughfall exclusion decreased foliage mass by $21 \%$ (Table 2, Figure 5a). While the foliage biomass was greater for the 2015 than the 2014 foliage cohort, treatment effects were consistent within years (Table 2). Average foliage mass for both years combined was $3550 \pm 226 \mathrm{~g}$ for the TA treatment and $2806 \pm 232 \mathrm{~g}$ for the TE treatment. Throughfall exclusion did not significantly affect peak foliage mass per unit sapwood area (Table 2) nor was there a significant interaction between throughfall exclusion and year (Table 2, Figure $5 b$ ).

Table 2. Statistical significance for the effects of year and throughfall exclusion (TE) on peak foliage mass, peak foliage mass per unit sapwood area, stable carbon isotope $\left(\delta^{13} \mathrm{C}\right)$, nitrogen concentration of the foliage, total height growth, total diameter at breast height $(\mathrm{DBH})$ growth, and total volume growth for the measurement period (2013-2014).

\begin{tabular}{ccccccccc}
\hline & $\begin{array}{c}\text { Peak Foliage } \\
\text { Mass }\end{array}$ & $\begin{array}{c}\text { Peak Foliage Mass Per } \\
\text { Sapwood Area }\end{array}$ & $\mathbf{\Psi}_{\mathbf{L}}$ & $\delta^{\mathbf{1 3}} \mathbf{C}$ & $\mathbf{N}$ & Height & DBH & Volume \\
\hline Year & 0.004 & 0.004 & $<0.0001$ & $<0.0001$ & 0.01 & 0.0001 & 0.005 & $<0.0001$ \\
TE & 0.047 & 0.60 & $<0.0001$ & 0.34 & 0.64 & 0.49 & 0.28 & 0.13 \\
Year $\times$ TE & 0.50 & 0.81 & 0.02 & 0.72 & 0.17 & 0.91 & 0.72 & 0.28 \\
\hline
\end{tabular}




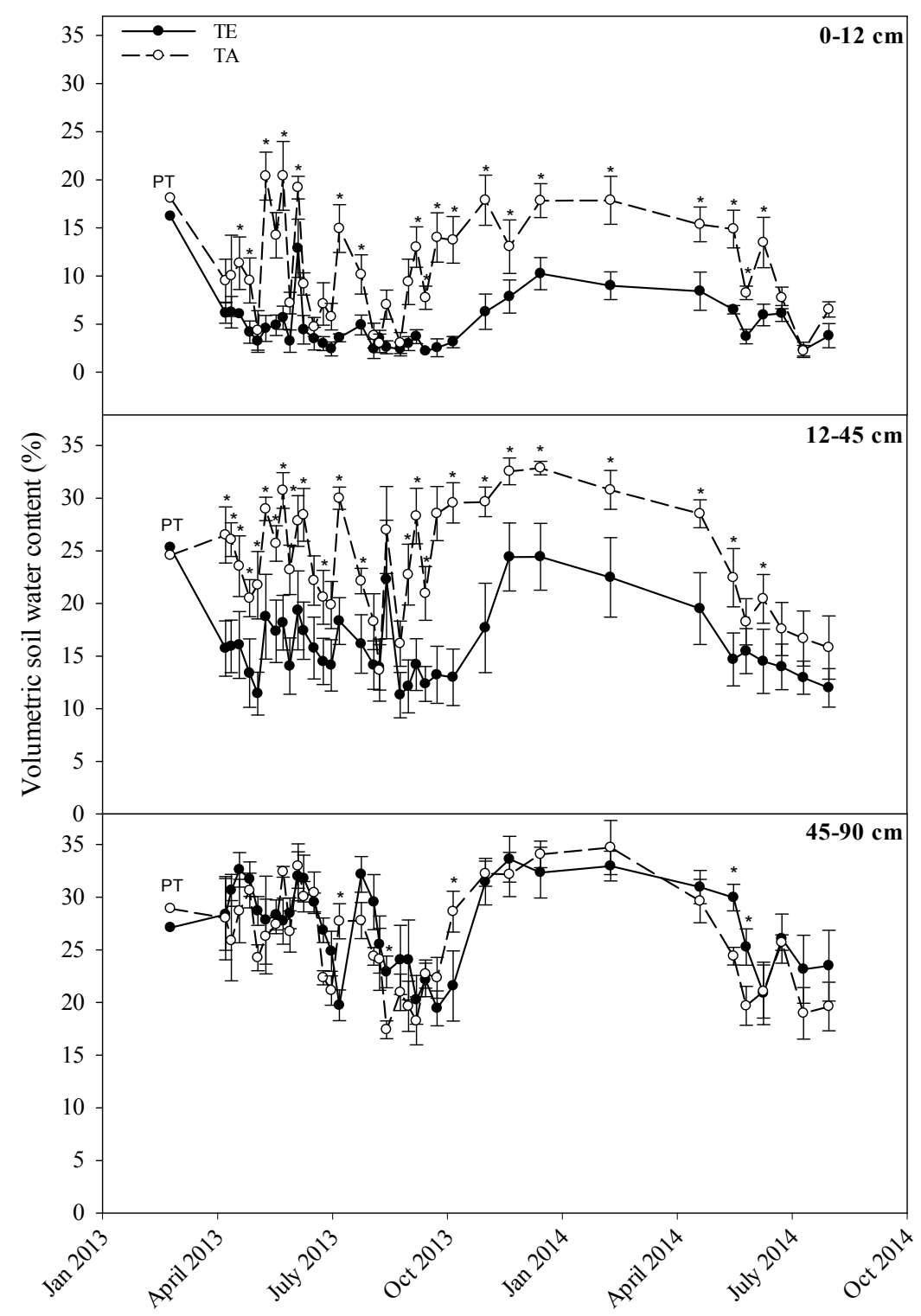

Figure 4. Mean volumetric soil water content (\%) between $0-12 \mathrm{~cm}, 12-45 \mathrm{~cm}$, and $45-90 \mathrm{~cm}$ in response to $100 \%$ throughfall exclusion (TE) and ambient throughfall (TA) treatments. An asterisk $\left({ }^{*}\right)$ above the data represents dates that treatments are significantly different $(p<0.1(n=5))$. Pre-treatment (PT) represents measurements before treatment application. 


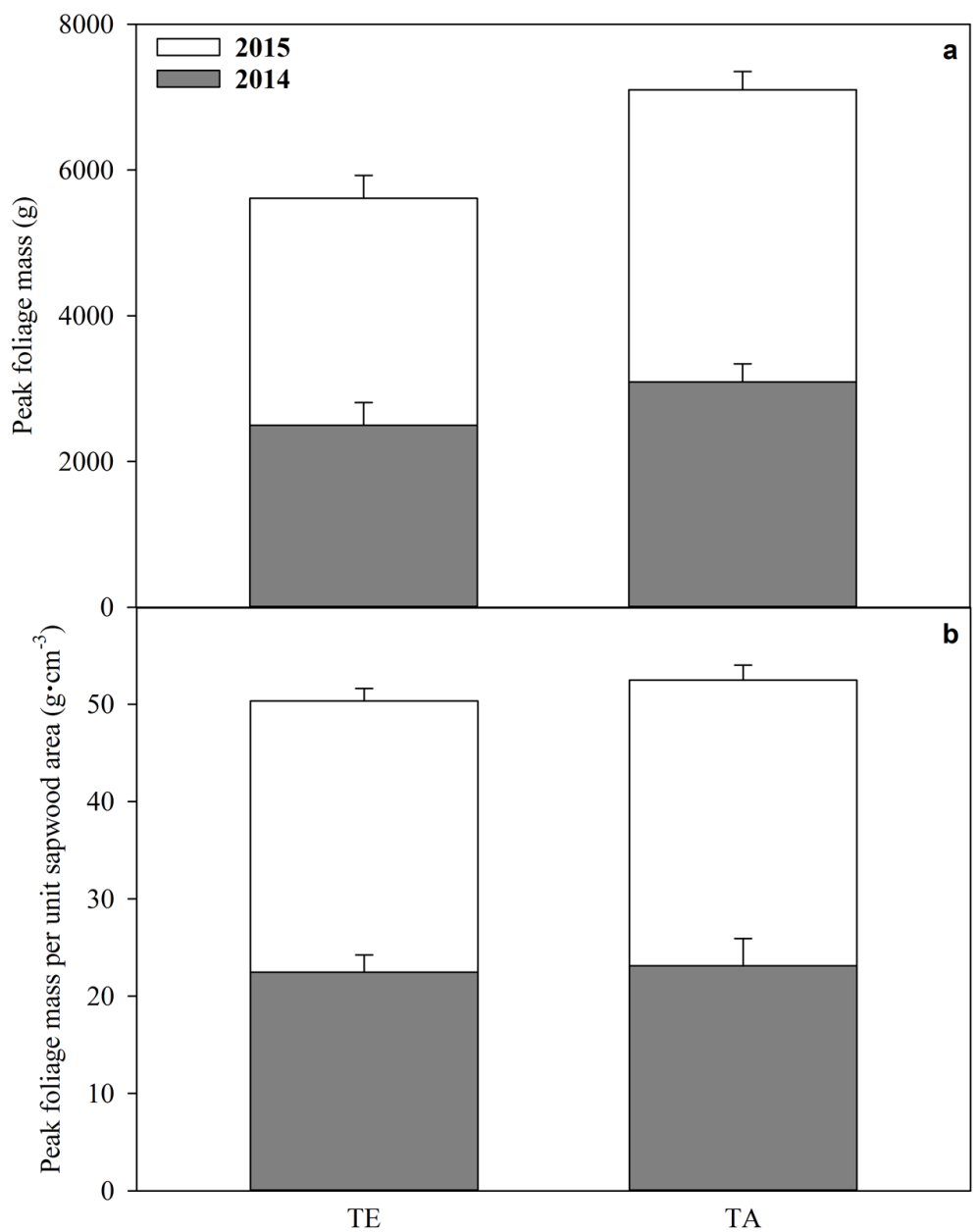

Figure 5. (a) Peak foliage mass and (b) peak foliage mass per unit sapwood area for the 2014 and 2015 foliage cohorts in response to $100 \%$ throughfall exclusion (TE) and ambient throughfall (TA) treatments. Error bars represent standard error of treatment means $(n=5)$.

\subsection{Physiology}

Leaf-level $P_{\text {net }}, g_{s}$, and $C_{i}$ varied by sampling date (Table 3) and followed similar trends. Throughfall exclusion marginally increased $\mathrm{g}_{\mathrm{s}}$ (Table 3 ) (Figure $6 \mathrm{~b}$ ) by $12 \%$ on average. Throughfall exclusion did not significantly affect leaf-level $P_{\text {net }}$ (Table 3) (Figure 6a) or $C_{i}$ (Table 3) (Figure 6c). The interaction between sampling date and throughfall exclusion was not significant for leaf gas exchange variables (Table 3). Throughfall exclusion (Table 3) caused more negative predawn $\Psi_{\mathrm{L}}$ following the second measurement date once the TE treatment began to take effect (Table 3, Figure 7a). Excluding the first two measurement dates, the differences were $34 \%$ on average. Throughfall exclusion caused more negative midday $\Psi_{\mathrm{L}}$, with the effects increasing over the course of the experiment (Table 3, Figure $7 \mathrm{~b}$ ). On dates where throughfall exclusion was significant for midday $\Psi_{\mathrm{L}}$, the differences were $23 \%$ on average. Across all dates, throughfall exclusion decreased midday $\Psi_{\mathrm{L}}$ by $17 \% . \delta^{13} \mathrm{C}$ varied by year (Table 2). Throughfall exclusion did not significantly affect $\delta^{13} \mathrm{C}$. Average $\delta^{13} \mathrm{C}$ was $-29.38 \% \pm 0.18 \%$ for the 2012 cohort, $-29.69 \%$ $\pm 0.16 \%$ for the 2013 cohort, and $-30.40 \% \pm 0.14 \%$ for the 2014 cohort. As with $\delta^{13} \mathrm{C}$, foliar $\mathrm{N}$ varied by year (Table 2). Throughfall exclusion did not significantly affect foliar N. Average foliar N was $9.82 \pm 0.44 \mathrm{mg} \cdot \mathrm{g}^{-1}$ for the 2012 cohort, $10.06 \pm 0.49 \mathrm{mg} \cdot \mathrm{g}^{-1}$ for the 2013 cohort, and $10.95 \pm 0.39 \mathrm{mg} \cdot \mathrm{g}^{-1}$ for the 2014 cohort. Throughfall exclusion did significantly increase specific leaf area of measured foliage, from $121.9 \pm 11.3 \mathrm{~cm}^{2} \cdot \mathrm{g}^{-1}$ for the TA treatment to $128.9 \pm 10.5 \mathrm{~cm}^{2} \cdot \mathrm{g}^{-1}$ for the TE treatment $(p=0.001)$. 
Table 3. Statistical significance for the effects of date and throughfall exclusion (TE) on leaf-level net photosynthesis $\left(\mathrm{P}_{\text {net }}\right)$, stomatal conductance $\left(\mathrm{g}_{\mathrm{s}}\right)$, intercellular $\mathrm{CO}_{2}\left(\mathrm{C}_{\mathrm{i}}\right)$, predawn leaf water potential $\left(\Psi_{\mathrm{L}}\right)$, midday leaf water potential $\left(\Psi_{\mathrm{L}}\right)$, whole-tree water use $(\mathrm{WU})$, and whole-tree water use per sapwood area (WUSA) for the entire measurement period (2013-2014). Bold values indicate significance at $p<0.1$.

\begin{tabular}{cccccccc}
\hline & $\mathbf{P}_{\text {net }}$ & $\mathbf{g}_{\mathbf{s}}$ & $\mathbf{C}_{\mathbf{i}}$ & Predawn $\boldsymbol{\Psi}_{\mathbf{L}}$ & Midday $\boldsymbol{\Psi}_{\mathbf{L}}$ & WU & WUSA \\
\hline Date & $<0.0001$ & $<0.0001$ & $<0.0001$ & $<0.0001$ & $<0.0001$ & $<0.0001$ & $<0.0001$ \\
$\mathrm{TE}$ & 0.64 & 0.09 & 0.12 & $<0.0001$ & $<0.0001$ & 0.22 & 0.45 \\
Date $\times \mathrm{TE}$ & 0.17 & 0.24 & 0.78 & 0.0002 & 0.04 & 0.99 & 0.85 \\
\hline
\end{tabular}

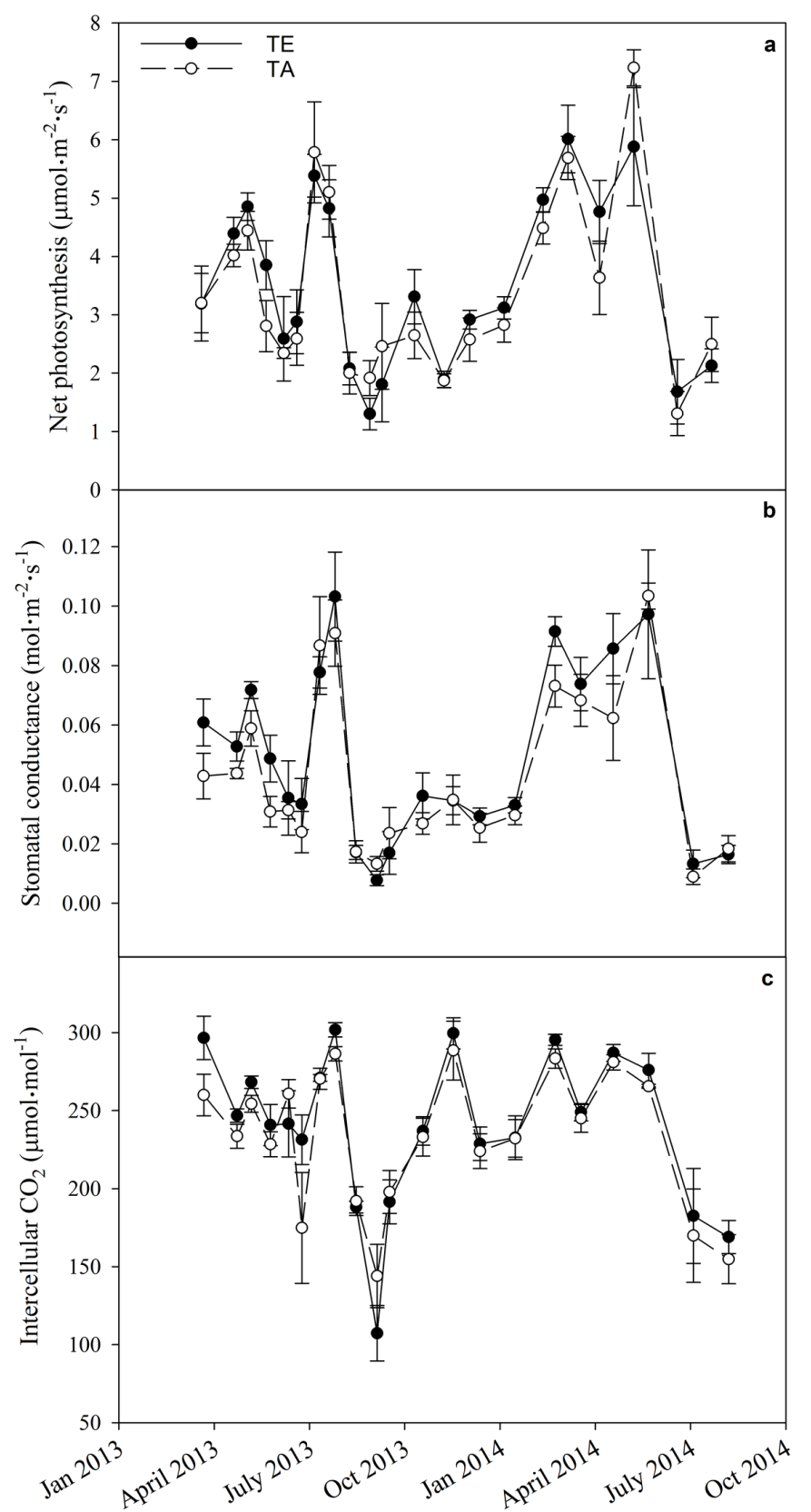

Figure 6. (a) Mean leaf-level net photosynthesis; (b) mean stomatal conductance; (c) intercellular CO2 in response to $100 \%$ throughfall exclusion (TE) and ambient throughfall (TA) treatments. Error bars represent standard error of treatment means $(n=5)$. 


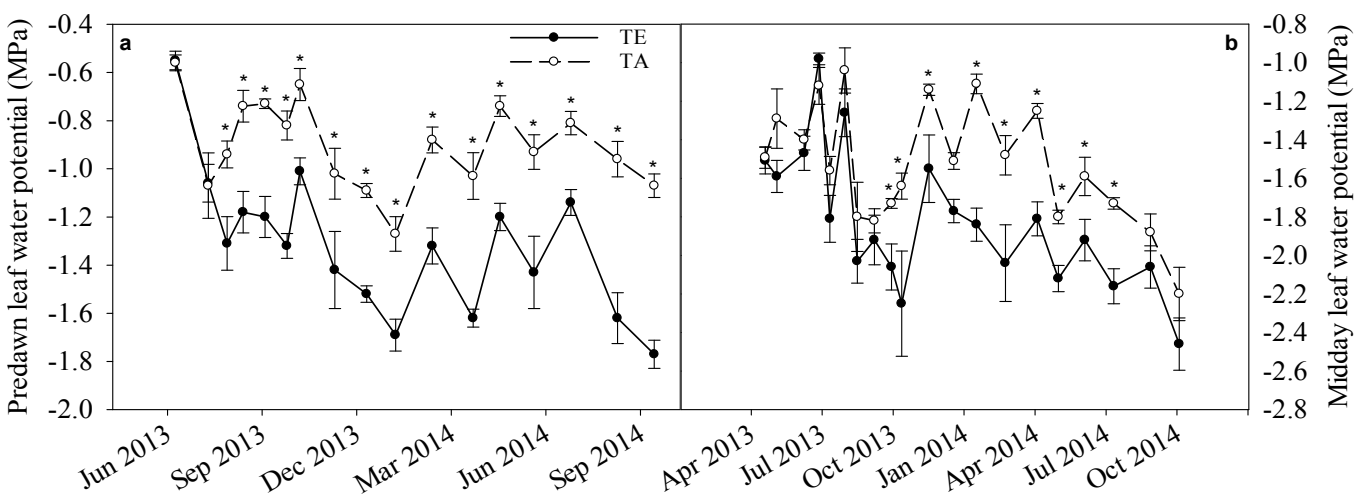

Figure 7. (a) Mean predawn leaf water potential and (b) mean midday leaf water potential in response to $100 \%$ throughfall exclusion (TE) and ambient throughfall (TA) treatments. An asterisk $\left(^{*}\right)$ above the data represents dates that TE effect is significant. Error bars represent standard error of treatment means $(n=5)$.

\subsection{Water Use}

Weekly whole-tree water use (WU) and water use per sapwood area (WUSA) varied by sampling date (Table 3) and followed similar trends. Throughfall exclusion reduced WU by $12 \%$ on average, but this difference was not significant (Table 3, Figure 8a). Throughfall exclusion increased WUSA by $6 \%$ on average, but this difference was not significant (Table 2, Figure $8 b$ ). There was no date by treatment interaction for WU (Table 3) or WUSA (Table 3).

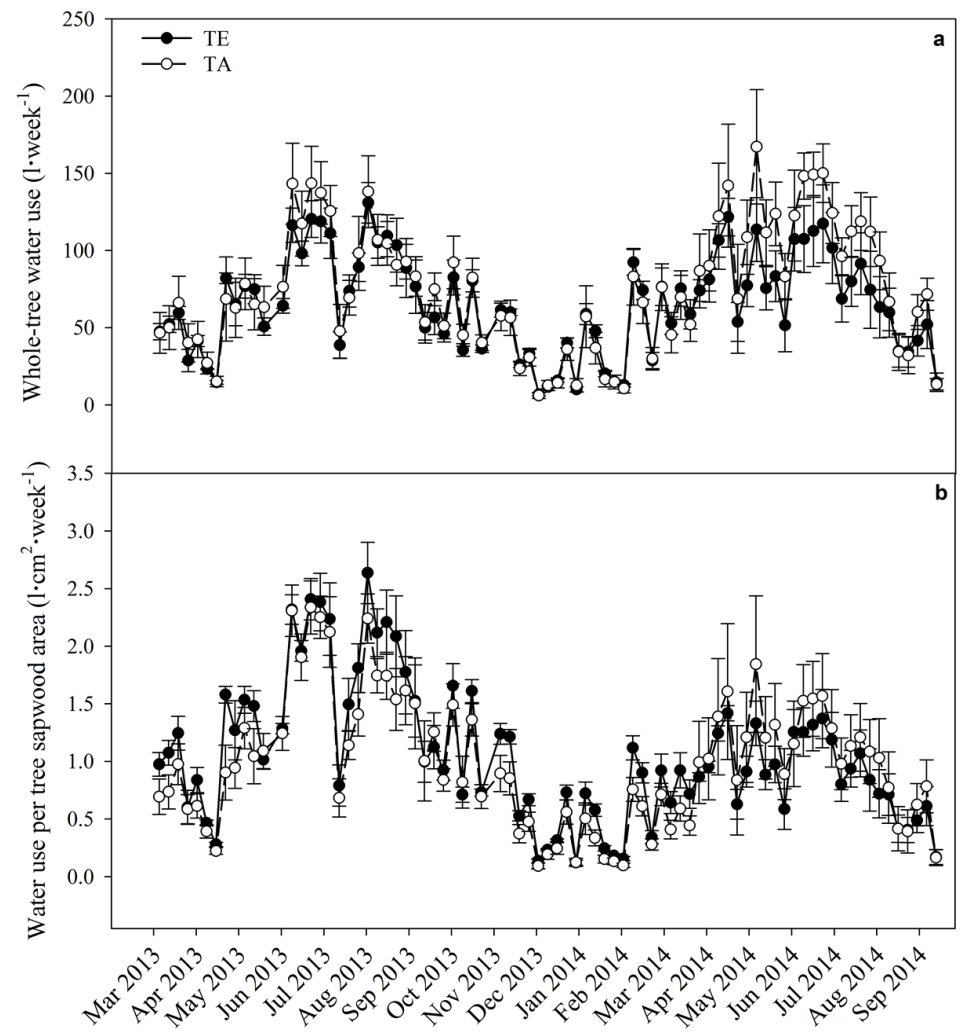

Figure 8. (a) Mean weekly total whole-tree water use and (b) mean weekly total water use per sapwood area in response to $100 \%$ throughfall exclusion (TE) and ambient throughfall (TA) treatments $(n=5)$. 


\subsection{Growth}

Before treatment application, mean tree height, DBH, and volume were $4.6 \pm 0.6 \mathrm{~m}, 6.8 \pm 0.8 \mathrm{~cm}$, and $0.012 \pm 0.002 \mathrm{~m}^{3}$ for the TE treatment and $4.7 \pm 0.4 \mathrm{~m}, 6.9 \pm 0.8 \mathrm{~cm}$, and $0.012 \pm 0.002 \mathrm{~m}^{3}$ for the TA treatment, respectively (Figure 9a-c). Throughfall exclusion did not significantly affect total height growth (Table 2) or DBH growth (Table 2). Throughfall exclusion reduced volume growth by 28\% (Table 2, Figure 9c). All measures of growth were greater for 2014 compared to 2013 (Table 2). Throughfall exclusion showed trends of reduced total height and DBH growth across the entire study period.

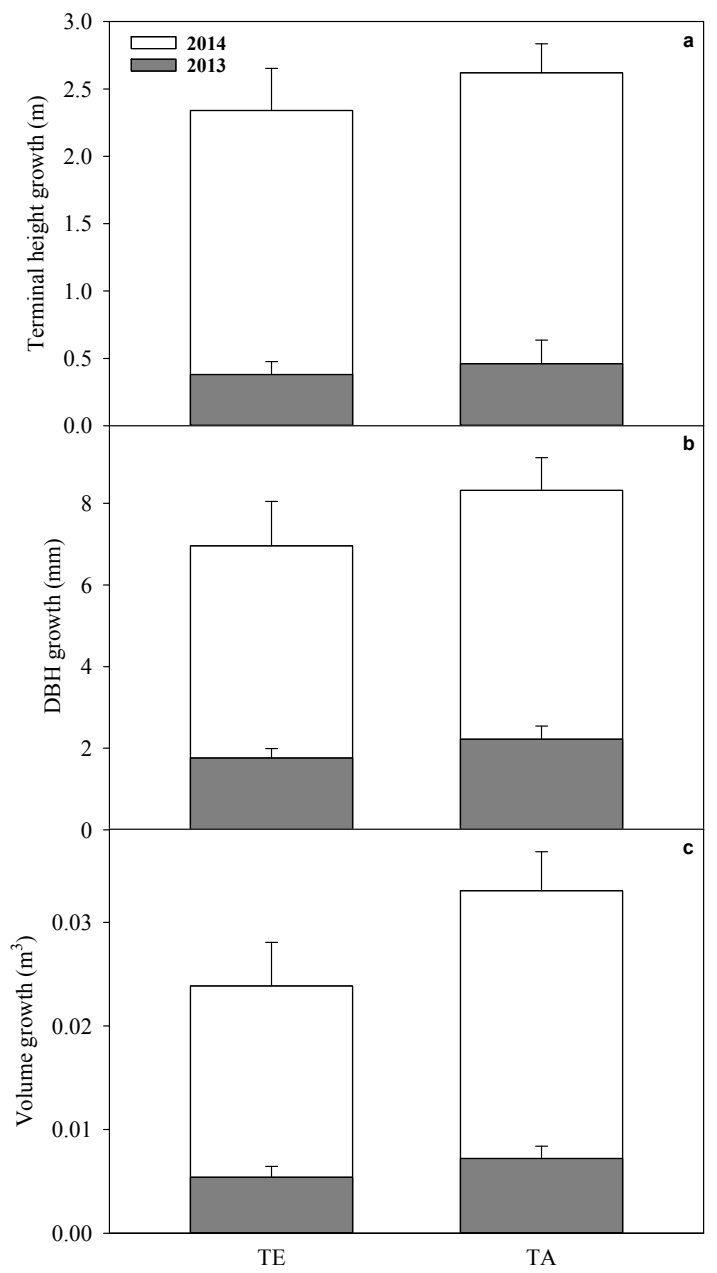

Figure 9. Total (a) height growth; (b) DBH growth; and (c) stem volume growth for 2013 and 2014 in response to $100 \%$ throughfall exclusion (TE) and ambient throughfall (TA) treatments. Error bars represent standard error of treatment means $(n=5)$.

\section{Discussion}

We hypothesized that sustained throughfall elimination would cause more negative leaf water potentials and decrease leaf gas exchange, tree water use, leaf biomass, and tree growth, with effects on leaf gas exchange the greatest. In support of our hypothesis, $100 \%$ throughfall exclusion for two growing seasons led to reduced VWC and more negative predawn and midday $\Psi_{\mathrm{L}}$. In turn, these effects of long-term drought caused a reduction in foliage mass. However, long-term throughfall exclusion did not significantly reduce leaf-level gas exchange or whole-tree water use. Given the lack of gas exchange and water use response, the net effect of long-term throughfall exclusion was to cause moderate, sustained water stress. Severe drought stress was avoided by roots accessing water below 
$45 \mathrm{~cm}$ soil depth where soil moisture was available or by upward movement of deeper water through capillary action. Although reduced foliage biomass of the throughfall excluded treatments did not significantly reduce water use, it did reduce potential water use and possibly altered the root:shoot ratio. The net effect of the reduction in leaf biomass was that when the relationship between water use and leaf biomass was calculated as annual water use per leaf biomass for 2014, both the TE and TA treatments had similar values of 1.01 and $0.99 \mathrm{~L} \cdot \mathrm{g}^{-1}$, respectively.

In our study, throughfall exclusion caused a large sustained decrease in predawn and midday $\Psi_{\mathrm{L}}$. Compared to throughfall reduction experiments on planted pine, both predawn and midday $\Psi_{\mathrm{L}}$ of the TE treated trees were more negative in our study than reported in previous research $[37,38]$. Mean predawn $\Psi_{\mathrm{L}}$ of the TE trees in our study reached levels more negative than those previously reported for planted loblolly pine during natural drought [34-36] but midday $\Psi_{\mathrm{L}}$ did not quite reach midday values previously reported [36,52]. Predawn $\Psi_{\mathrm{L}}$ reflects plant water status after a time of recovery with stomata closed while midday $\Psi_{\mathrm{L}}$ is affected by transpiration rate as controlled by VPD and stomatal conductance. Our midday $\Psi_{\mathrm{L}}$ of the TE trees could have been less negative than some of those reported because natural droughts often occur during periods of very high evaporative demand or because the trees originating from the Western Gulf region might close their stomata sooner in response to water stress than seed sources from further east in the range.

The excluders were effective at eliminating throughfall. However, deeper soil moisture $(45-90 \mathrm{~cm}$ depth) did not show a decline. This was probably due to a combination of lower rooting density at that depth and subsurface movement of deeper soil water. In loblolly pine, greater than $95 \%$ of root biomass is in the top $60 \mathrm{~cm}$ of the soil of both dry and wet soils [53,54], with $70 \%$ to $80 \%$ commonly located in the top $20 \mathrm{~cm}$ of soil [55] and the majority of absorptive roots within the top $15 \mathrm{~cm}$ of the soil [51]. While deeper roots are less common, roots accessing the more available, deeper soil water may have been able to prevent more severe drought stress. Subsurface water moves from areas of higher soil water potential to areas of lower soil water potential. Even though we trenched down to $60 \mathrm{~cm}$, lined the trench with plastic, and placed the site on a ridge, lateral soil water movement may have occurred, keeping VWC from 45-90 cm soil depth similar throughout the duration of the study. The net effect was that although we eliminated $100 \%$ of throughfall, the treatment we imposed probably represented sustained, moderate drought stress rather than severe drought stress sufficient to cause mortality. This differs from other situations where a fraction of throughfall is removed [56], in that the surface soil layers never recharged with $100 \%$ exclusion treatment. Because of access to deeper soil water, this study failed to establish conditions sufficient to simulate extreme drought which might occur under warmer climate conditions with more sporadic precipitation.

Rather than causing stomatal closure and a reduction in leaf-level gas exchange, the sustained drought treatment caused a downward shift in leaf biomass. Morphological changes such as reduced leaf area or biomass can occur in some tree species in response to drought over longer time scales [16,57], while short-term and/or less severe drought cause stomatal closure without affecting foliage mass [57]. If converted to a leaf area basis, the higher specific leaf area of the TE treatment decreases the treatment effects from a $21 \%$ reduction on a leaf biomass to a $14 \%$ reduction on a leaf area basis.

Trees can employ different strategies during drought, ranging from water-conserving behavior known as isohydric regulation to a riskier, less conservative strategy known as anisohydric regulation $[10,58]$. Isohydric species reduce stomatal conductance as soil water decreases and the demand for water in the atmosphere increases during drought conditions, maintaining relatively constant midday leaf water potential. In contrast, anisohydric species allow midday leaf water potential to decline as soil dries during drought, thus maintaining stomatal conductance and $\mathrm{CO}_{2}$ assimilation [10,58,59]. Trees experiencing long-term, persistent drought in our study did not maintain leaf water potentials or reduce stomatal conductance, which could indicate an anisohydric response strategy to long-term drought conditions. Part of what may have allowed the TE treatment trees to maintain physiological function at more negative water potentials could have been due to osmotic adjustment. 
In our study, throughfall exclusion reduced foliage mass by $21 \%$, which is consistent with the effects of severe or sustained drought. Current-year loblolly pine needles are influenced by conditions during the previous two years [60]. In comparison, a recent study conducted in the same stand, but different area found that a more moderate reduction in throughfall of approximately $30 \%$ decreased leaf area index by $8.5 \%$ [61]. Similarly, a $12 \%$ reduction in foliage mass from throughfall reduction in an 18-year-old loblolly pine plantation in Louisiana was reported [37]. While we expect that the direct effects of soil moisture deficit had the major influence over leaf development, reduced soil water content could have reduced nutrient turnover and availability in the soil which could have slowed leaf biomass development. However, no differences in foliar nitrogen occurred between treatments.

Reductions in VWC often result in reduced stomatal conductance to conserve water, subsequently reducing leaf-level photosynthesis and growth in loblolly pine [9,15]. This is consistent with recent loblolly pine throughfall reduction studies $[37,38,41]$, as well as drought induced experiments on piñon pine (Pinus edulis) and juniper (Juniperus monosperma) [24,27]. For loblolly pine under water stress, $C_{i}$ (a surrogate for water use efficiency) has been found to decrease $[15,41,62]$. In contrast, $100 \%$ throughfall exclusion in this study increased $g_{s}$ and the lack of differences in leaf-level $P_{n e t}, C_{i}$, and $\delta^{13} \mathrm{C}$ in our study could be due to a combination of the significant reduction in peak foliage mass and an anisohydric response to the consistent reductions in VWC in $0-45 \mathrm{~cm}$ soil depth. The increases in $\mathrm{g}_{\mathrm{s}}$ for TE trees compared to TA trees but not leaf-level $P_{\text {net }}$ could be from non-stomatal limitation to water stress such that higher $g_{s}$ was necessary to maintain $P_{\text {net }}$. Mesophyll conductance has been recognized as being more sensitive to water stress than $\mathrm{g}_{\mathrm{s}}[62,63]$, which may have triggered such a tradeoff.

Throughfall exclusion did not significantly reduce WU or WUSA in our study which contrasts with recent loblolly pine throughfall reduction studies measuring WU [61] and stand-level transpiration $[39,40]$. The lack of effect of throughfall exclusion on WU or WUSA in the current study is consistent with our leaf gas exchange results. There were nonsignificant trends of lower WU and higher WUSA in the throughfall exclusion treatment, especially during the summer, which is consistent with reduced foliage mass. Our relatively low sample size may have limited our ability to detect significant effects. In contrast, the increased $g_{s}$ in the TE treatment could be increasing WU even though foliage mass was reduced, as water use is highly responsive to leaf quantity and $g_{s}[64,65]$.

Given no differences in leaf-level $P_{\text {net}}$, reduced tree stem volume growth of the TE treatment was probably related to reduced leaf development as there is a direct correlation between leaf quantity and growth in loblolly pine [66,67]. Growth in 2014 was much greater than 2013 probably due to trenching and resultant damage to root systems immediately before the 2013 growing season. Reduced latewood production has been found to be proportional to the amount of cross-sectional root area severed [68]. For our site, in the same location but separate from this study, three trees were $100 \%$ excluded but not trenched. Mean volume growth for the 2013 growing season for these excluded, non-trenched trees was $40 \%$ greater than trees in the TE treatment and $30 \%$ greater than trees in the TA treatment.

\section{Conclusions}

Our results indicate that $100 \%$ throughfall exclusion surrounding individual trees decreased soil moisture, reduced leaf water potentials, reduced foliage biomass, and decreased stem volume growth. However, contrary to our initial hypothesis, 100\% throughfall exclusion did not reduce leaf-level gas exchange or water use. Rather, 100\% throughfall exclusion trees avoided stomatal closure while reducing foliage biomass. In turn, stomatal conductance maintained water use without reaching leaf water potential values low enough to cause permanent damage. These results indicate that loblolly pine on similar sites under sustained, moderate drought change their water conserving strategies and make morphological changes in regards to reduced leaf biomass in order to maintain productivity while avoiding severe and potentially fatal levels of water stress. During sustained, consistent moderate drought, morphological water conserving strategies rather than physiological acclimations were more important for avoiding severe and potentially fatal levels of water stress for loblolly pine on similar sites. 
Acknowledgments: Funding was provided by The Pine Integrated Network: Education, Mitigation, and Adaptation Project (PINEMAP), a Coordinated Agriculture Project funded by the United States Department of Agriculture-National Institute of Food and Agriculture, Award \#2011-68002-30185, McIntire-Stennis project OKLO 2929, and the Oklahoma Agricultural Experiment Station. We are especially thankful to Ed Hurliman for providing use of his property for this study, Bob Heinemann and the staff at the Kiamichi Forestry Research Station for help with installations and data collections. Special thanks to The Pine Integrated Network: Education, Mitigation, and Adaptation Project (PINEMAP) interns Brittany Baggott and Alex Hardison, and Oklahoma State University interns Rodrigo Carvalhais, Michell Scaff, Arthur Dias Cagnani, Fernanda Bortolheiro, and Lays Dal Santo Francisco, and Oklahoma State University Postdoctoral Research Associate Dipesh K.C. for their assistance in the field and laboratory.

Author Contributions: A.M. designed and implemented the study, collected data, and was the lead in data analysis and writing the manuscript. R.W. helped design and implement the study and assisted with data analysis and writing. D.W. helped design and implement the study and assisted with data analysis and writing. C.M. helped with implementing the study, collected data, maintained the study site, and helped with writing.

Conflicts of Interest: The authors declare no conflict of interest.

\section{References}

1. Wear, D.N.; Greis, J.G. The Southern Forest Futures Project: Summary Report; USDA Forest Service Southern Research Station: Asheville, NC, USA, 2012.

2. Oswalt, S.N.; Smith, W.B.; Miles, P.D.; Pugh, S.A. Forest Resources of the United States, 2012: A Technical Document Supporting the Forest Service 2015 Update of the RPA Assessment; U.S. Department of Agriculture, Forest Service, Washington Office: Washington, DC, USA, 2014.

3. Collins, M.; Knutti, R.; Arblaster, J.; Dufresne, J.-L.; Fichefet, T.; Friedlingstein, P.; Gao, X.; Gutowski, W.J.; Johns, T.; Krinner, G.; et al. Long-term climate change: Projections, commitments and irreversibility. In Climate Change 2013: The Physical Science Basis. Contribution of Working Group I to the Fifth Assessment Report of the Intergovernmental Panel on Climate Change; Stocker, T.F., Qin, D., Plattner, G.-K., Tignor, M., Allen, S.K., Boschung, J., Nauels, A., Xia, Y., Bex, V., Midgley, P.M., Eds.; Cambridge University Press: Cambridge, UK; New York, NY, USA, 2013; pp. 1039-1106.

4. Walsh, J.; Wuebbles, D.; Hayhoe, K.; Kossin, J.; Kunkel, K.; Stephens, G.; Thorne, P.; Vose, R.; Wehner, M.; Willis, J.; et al. Chapter 2: Our changing climate. In Climate Change Impacts in the United States: The Third National Climate Assessment; Melillo, J.M., Richmond, T.C., Yohe, G.W., Eds.; U.S. Global Change Research Program: Washington, DC, USA, 2014; pp. 19-67.

5. $\quad$ Breshears, D.D.; Adams, H.D.; Eamus, D.; McDowell, N.G.; Law, D.J.; Will, R.E.; Williams, A.P.; Zou, C.B. The critical amplifying role of increasing atmospheric moisture demand on tree mortality associated with regional die off. Front. Plant Sci. 2013, 4, 266. [CrossRef] [PubMed]

6. Will, R.E.; Wilson, S.M.; Zou, C.B.; Hennessey, T.C. Increased VPD due to higher temperature leads to greater transpiration and faster mortality during drought for tree seedlings common to the forest-grassland ecotone. New Phytol. 2013, 200, 366-374. [CrossRef] [PubMed]

7. Seager, R.; Hooks, A.; Williams, A.P.; Cook, B.; Nakamura, J. Climatology, variability, and trends in the U.S. vapor pressure deficit, and important fire-related meteorological quantity. J. Appl. Meteorol. Climatol. 2015, 54, 1121-1141. [CrossRef]

8. Kramer, P.J.; Boyer, J.S. Water Relations of Plants and Soils; Academic Press: London, UK, 1995; pp. $344-374$.

9. Chaves, M.M.; Maroco, J.P.; Pereira, J. Understanding plant response to drought-from genes to the whole plant. Funct. Plant Biol. 2003, 30, 239-264. [CrossRef]

10. McDowell, N.; Pockman, W.T.; Allen, C.D.; Breshears, D.D.; Cobb, N.; Kolb, T.; Plaut, J.; Sperry, J.; West, A.; Williams, D.G.; et al. Mechanisms of plant survival and mortality during drought: Why do some plants survive while others succumb to drought? New Phytol. 2008, 178, 719-739. [CrossRef] [PubMed]

11. Fensham, R.J.; Fairfax, R.J.; Ward, D.P. Drought-induced tree death in savanna. Glob. Chang. Biol. 2009, 15, 380-387. [CrossRef]

12. Allen, C.D.; Macalady, A.K.; Chenchouni, H.; Bachelet, D.; McDowell, N.; Vennetier, M.; Kitzberger, T.; Rigling, A.; Breshears, D.D.; Hogg, E.H.; et al. A global overview of drought and heat-induced tree mortality reveals emerging climate change risks for forests. For. Ecol. Manag. 2010, 259, 660-684. [CrossRef] 
13. Anderegg, W.R.L.; Berry, J.A.; Smith, D.D.; Sperry, J.S.; Anderegg, L.D.L.; Field, C.B. The roles of hydraulic and carbon stress in a widespread climate-induced forest die-off. Proc. Natl. Acad. Sci. USA 2012, 109, 233-237. [CrossRef] [PubMed]

14. Chaves, M.M. Effects of water deficits on carbon assimilation. J. Exp. Bot. 1991, 42, 1-16. [CrossRef]

15. Teskey, R.O.; Fites, J.A.; Samuelson, L.J.; Bongarten, B.C. Stomatal and nonstomatal limitations to net photosynthesis in Pinus taeda L. under different environmental conditions. Tree Physiol. 1986, 2, 131-142. [CrossRef] [PubMed]

16. Mencuccini, M.; Grace, J. Climate influences the leaf area/sapwood area ratio in Scots pine. Tree Physiol. 1994, 15, 1-10. [CrossRef]

17. Hennessey, T.C.; Dougherty, P.M.; Cregg, B.M.; Wittwer, R.F. Annual variation in needle fall of a loblolly pine stand in relation to climate and stand density. For. Ecol. Manag. 1992, 51, 329-338. [CrossRef]

18. Hubbard, R.M.; Ryan, M.G.; Stiller, V.; Sperry, J.S. Stomatal conductance and photosynthesis vary linearly with plant hydraulic conductance in ponderosa pine. Plant Cell Environ. 2001, 24, 113-121. [CrossRef]

19. Whitehead, D.; Beadle, C.L. Physiology regulation of productivity and water use in Eucalyptus: A review. For. Ecol. Manag. 2004, 193, 113-140. [CrossRef]

20. Pallardy, S.G.; Rhoads, J.L. Drought effects leaf abscission and leaf production in Populus clones. In Proceedings of the 11th Central Hardwood Forest Conference, Columbia, MO, USA, 23-26 March 1997; Pallardy, S.G., Cecich, R.A., Garrett, H.G., Johnson, P.S., Eds.; U.S. Department of Agriculture, Forest Service, North Central Forest Experiment Station: St. Paul, MN, USA, 1997; pp. 373-383.

21. Allen, C.D.; Breshears, D.D. Drought-induced shift of a forest woodland ecotone: Rapid landscape response to climate variation. Proc. Natl. Acad. Sci. USA 1998, 95, 14839-14842. [CrossRef] [PubMed]

22. Allen, C.D.; Breshears, D.D. Climate-Induced Forest Dieback as an Emergent Global Phenomenon; Eos, Transitions American Geophysical Union: San Jose, CA, USA, 2007; Volume 88, pp. 504-505.

23. Dobbertin, M.; Wermelinger, B.; Bigler, C.; Bürgi, M.; Carron, M.; Forster, B.; Gimmi, U.; Rigling, A. Linking increasing drought stress to scots pine mortality and bark beetle infestations. Sci. World J. 2007, 7, 231-239. [CrossRef] [PubMed]

24. Adams, H.D.; Guardiola-Claramonte, M.; Barron-Gafford, G.A.; Villegas, J.C.; Breshears, D.D.; Zou, C.B.; Troch, P.A.; Huxman, T.E. Temperature sensitivity of drought-induced tree mortality portends increased regional die-off under global-change-type drought. Proc. Natl. Acad. Sci. USA 2009, 106, 7063-7066. [CrossRef] [PubMed]

25. Galvez, D.A.; Landhäusser, S.M.; Tyree, M.T. Root carbon reserve dynamics in aspen seedlings: Does simulated drought induce reserve limitation? Tree Physiol. 2011, 31, 250-257. [CrossRef] [PubMed]

26. Plaut, J.; Wadsworth, W.D.; Pangle, R.; Yepez, E.A.; McDowell, N.G.; Pockman, W.T. Reduced transpiration response to precipitation pulses precedes mortality in a piñon-juniper woodland subject to prolonged drought. New Phytol. 2013, 200, 375-387. [CrossRef] [PubMed]

27. Pangle, R.E.; Limousin, J.M.; Plaut, J.A.; Yepez, E.A.; Hudson, P.J.; Boutz, A.L.; Gehres, N.; Pockman, W.T.; McDowell, N.G. Prolonged experimental drought reduces plant hydraulic conductance and transpiration and increases mortality in a piñon-juniper woodland. Ecol. Evol. 2015, 5, 1618-1638. [CrossRef] [PubMed]

28. Adams, H.D.; Kolb, T.E. Tree growth response to drought and temperature along an elevation gradient on a mountain landscape. J. Biogeogr. 2005, 32, 1629-1640. [CrossRef]

29. Bréda, N.; Huc, R.; Granier, A.; Dreyer, E. Temperate forest trees and stands under severe drought: A review of ecophysiological responses, adaptation processes and long-term consequences. Ann. For. Sci. 2006, 63, 525-544. [CrossRef]

30. Attia, Z.; Domec, J.-C.; Oren, R.; Way, D.A.; Moshelion, M. Growth and physiological responses of isohydric and anisohydric poplars to drought. J. Exp. Bot. 2015, 66, 4373-4381. [CrossRef] [PubMed]

31. Perry, M.A.; Mitchell, R.J.; Zutter, B.R.; Glover, G.R.; Gjerstad, D.H. Seasonal variation in competitive effect on water stress and pine responses. Can. J. For. Res. 1994, 24, 1440-1449. [CrossRef]

32. Groninger, J.W.; Seiler, J.R.; Zedaker, S.M.; Berrang, P.C. Effects of $\mathrm{CO}_{2}$ concentration and water availability on growth and gas exchange in greenhouse-grown miniature stands of loblolly pine and red maple. Funct. Ecol. 1996, 10, 708-716. [CrossRef]

33. Barnes, A.D. Effects of phenology, water availability and seed source on loblolly pine biomass partitioning and transpiration. Tree Physiol. 2002, 22, 733-740. [CrossRef] [PubMed] 
34. Cregg, B.M.; Dougherty, P.M.; Hennessey, T.C. Growth and wood quality of young loblolly pine trees in relation to stand density and climatic factors. Can. J. For. Res. 1988, 18, 851-858. [CrossRef]

35. Ford, C.R.; Goranson, C.E.; Mitchell, R.J.; Will, R.E.; Teskey, R.O. Modeling canopy transpiration using time series analysis: A case study illustrating the effect of soil moisture deficit on Pinus taeda. Agric. For. Meteorol. 2005, 130, 163-175. [CrossRef]

36. Domec, J.-C.; Noormets, A.; King, J.S.; Sun, G.; McNulty, S.G.; Gavazzi, M.J.; Boggs, J.L.; Treasure, E.A. Decoupling the influence of leaf and root hydraulic conductances on stomatal conductance and its sensitivity to vapour pressure deficit as soil dries in a drained loblolly pine plantation. Plant Cell Environ. 2009, 32, 980-991. [CrossRef] [PubMed]

37. Tang, Z.; Sword Sayer, M.A.; Chambers, J.L.; Barnett, J.P. Interactive effects of fertilization and througfall exclusion on the physiological responses and whole-tree carbon uptake of mature loblolly pine. Can. J. Bot. 2004, 82, 850-861. [CrossRef]

38. Samuelson, L.J.; Pell, C.J.; Stokes, T.A.; Bartkowiak, S.M.; Akers, M.K.; Kane, M.; Markewitz, D.; McGuire, M.A.; Teskey, R.O. Two-year throughfall and fertilization effects on leaf physiology and growth of loblolly pine in the Georgia Piedmont. For. Ecol. Manag. 2014, 330, 29-37. [CrossRef]

39. Bartkowiak, S.M.; Samuelson, L.J.; McGuire, M.A.; Teskey, R.O. Fertilization increases sensitivity of canopy stomatal conductance and transpiration to throughfall reduction in an 8-year-old loblolly pine plantation. For. Ecol. Manag. 2015, 354, 87-96. [CrossRef]

40. Ward, E.J.; Domec, J.-C.; Laviner, M.A.; Fox, T.R.; Sun, G.; McNulty, S.; King, J.; Noormets, A. Fertilization intensifies drought stress: Water use and stomatal conductance of Pinus taeda in a midrotation fertilization and throughfall reduction experiment. For. Ecol. Manag. 2015, 355, 72-82. [CrossRef]

41. Maggard, A.O.; Will, R.E.; Wilson, D.S.; Meek, C.R.; Vogel, J.G. Fertilization reduced stomatal conductance but not photosynthesis of Pinus taeda which compensated for lower water availability in regards to growth. For. Ecol. Manag. 2016, Accepted.

42. Rahman, M.S.; Messina, M.G.; Newton, R.J. Performance of loblolly pine (Pinus taeda L.) seedlings and micropropagated plantlets on an east Texas site II. Water relations. For. Ecol. Manag. 2003, 178, 257-270. [CrossRef]

43. Natural Resources Conservation Service, United States Department of Agriculture. Official Soil Series Descriptions and Series Classification. Available online: http://soilseries.sc.egov.usda.gov (accessed on 24 July 2016).

44. The Oklahoma Mesonet. Daily Data Retrieval. Available online: http://mesonet.org/index.php/weather/ daily (accessed on 24 July 2016).

45. Allen, R.G.; Pereira, L.S.; Raes, D.; Smith, M. Crop Evapotranspiration-Guidelines for Computing Crop Water Requirements-FAO Irrigation and Drainage Paper 56; Food and Agriculture Organization (FAO) of the United Nations: Rome, Italy, 1998.

46. Burkhart, H.D. Cubic-foot volume of loblolly pine to any merchantable top limit. South. J. Appl. For. 1977, 1, 7-9.

47. Granier, A. Une nouvelle methode pour la mesure du flux de seve brute dans le tronc des arbes. Ann. For. Sci. 1985, 42, 193-200. [CrossRef]

48. Tateishi, M.; Kumagai, T.Ä.; Utsumi, Y.; Umebayashi, T.; Shiiba, Y.; Inoue, K.; Kaji, K.; Cho, K.; Otsuki, K. Spatial variations in xylem sap flux density in evergreen oak trees with radial-porous wood: Comparisons with anatomical observations. Trees Struct. Funct. 2008, 22, 23-30. [CrossRef]

49. Ward, E.J.; Oren, R.; Bell, D.M.; Clark, J.S.; McCarthy, H.R.; Kim, H.-S.; Domec, J.-C. The effects of elevated $\mathrm{CO}_{2}$ and nitrogen fertilization on stomatal conductance estimated from 11 years of scaled sap flux measurements at Duke FACE. Tree Physiol. 2013, 33, 135-151. [CrossRef] [PubMed]

50. Granier, A. Evaluation of transpiration in a Douglas-fir stand by means of sap flow measurements. Tree Physiol. 1987, 3, 309-320. [CrossRef] [PubMed]

51. Schultz, R.P. Loblolly Pine: The Ecology and Culture of Loblolly Pine (Pinus taeda L.); U.S. Department of Agriculture, Forest Service, Washington Office: Washington, DC, USA, 1997.

52. Hacke, U.G.; Sperry, J.S.; Ewers, B.E.; Ellsworth, D.S.; Schäfer, K.V.R.; Oren, R. Influence of soil porosity on water use in Pinus taeda. Oecologia 2000, 124, 495-505. [CrossRef]

53. Harris, W.F.; Kinerson, R.S.; Edwards, N.T. Comparison of below-ground biomass of natural deciduous forests and loblolly pine plantations. Pedobiologia 1977, 17, 369-381. 
54. Brewer, C.W.; Linnartz, N.E. Soil moisture utilization by mature loblolly pine stands in the Coastal Plain of southeastern Louisiana. In Proceedings of the Soil Moisture Site Productivity Symposium, Myrtle Beach, SC, USA, 1-3 November 1977; Balmer, W.E., Ed.; USDA Forest Service, Southeastern Area, State and Private Forestry, 1978; pp. 296-306.

55. Box, B.H. A Study of Root Extension and Biomass in a Six-Year-Old Pine Plantation in Southeast Louisiana. Ph.D. Thesis, Duke University, School of Forest Resources, Durham, NC, USA, 1967.

56. Will, R.E.; Fox, T.; Akers, M.; Domec, J.-C.; González-Benecke, C.; Jokela, E.J.; Kane, M.; Laviner, M.A.; Lokuta, G.; Markewitz, D.; et al. A range-wide experiment to investigate nutrient and soil moisture interactions in loblolly pine plantations. Forests 2015, 6, 2014-2028. [CrossRef]

57. Kramer, P.J. Water Relations of Plants; Academic Press: New York, NY, USA, 1983.

58. Sade, N.; Gebremedhin, A.; Moshelion, M. Risk-taking plants: Anisohydric behavior as a stress-resistance trait. Plant Signal Behav. 2012, 7,767-770. [CrossRef] [PubMed]

59. Moshelion, M.; Halperin, O.; Wallach, R.; Oren, R.; Way, D.A. Role of aquaporins in determining transpiration and photosynthesis in waterstressed plants: Crop water-use efficiency, growth and yield. Plant Cell Environ. 2015, 38, 1785-1793. [CrossRef] [PubMed]

60. Hebert, M.T.; Jack, S.B. Leaf area index and site water balance of loblolly pine (Pinus taeda L.) across a precipitation gradient in East Texas. For. Ecol. Manag. 1998, 105, 273-282. [CrossRef]

61. Maggard, A.O. Response of Mid-Rotation Loblolly Pine (Pinus taeda L.) to Fertilization and Reduced Water Availability in Southeastern Oklahoma. Ph.D. Thesis, Oklahoma State University, Stillwater, OK, USA, May 2016.

62. Green, T.H.; Mitchell, R.J. Effects of nitrogen on the response of loblolly pine to water stress. I. Photosynthesis and stomatal conductance. New Phytol. 1992, 122, 627-633. [CrossRef]

63. Grassi, G.; Manani, F. Stomatal, mesophyll conductance and biochemical limitations to photosynthesis as affected by drought and leaf ontogeny in ash and oak trees. Plant Cell Environ. 2005, 28, 834-849. [CrossRef]

64. Ni, B.-R.; Pallardy, S.G. Stomatal and nonstomatal limitations to net photosynthesis in seedlings of woody angiosperms. Plant Physiol. 1992, 99, 1502-1508. [CrossRef] [PubMed]

65. Sun, G.; Alstad, K.; Chen, J.; Chen, S.; Ford, C.R.; Lin, G.; Liu, C.; Lu, N.; McNulty, S.G.; Miao, H.; et al. A general predictive model for estimating monthly ecosystem evapotranspiration. Ecohydrology 2011, 4, 245-255. [CrossRef]

66. Albaugh, T.J.; Allen, H.L.; Daugherty, P.M.; Kress, L.W.; King, J.S. Leaf area and above-and below-ground growth responses of loblolly pine to nutrient and water additions. For. Sci. 1998, 44, 317-327.

67. Jokela, E.J.; Dougherty, P.M.; Martin, T.A. Production dynamics of intensively managed loblolly pine stands in the southern United States: A synthesis of seven longterm experiments. For. Ecol. Manag. 2004, 192, 117-130. [CrossRef]

68. Carlson, W.C.; Harrington, C.A.; Farnum, P.; Hallgren, S.W. Effects of root severing treatments on loblolly pine. Can. J. For. 1988, 18, 1376-1385. [CrossRef]

(C) 2016 by the authors; licensee MDPI, Basel, Switzerland. This article is an open access article distributed under the terms and conditions of the Creative Commons Attribution (CC-BY) license (http://creativecommons.org/licenses/by/4.0/). 